\title{
Influence of Agricultural Wastes and Incubation Period on Aggregate Stability in Sandy Soil
}

\author{
Ahmed Farid Saad
}

\begin{abstract}
A laboratory experiment was conducted to examine the influence of various organic materials on soil aggregate stability of sandy soil collected from Al-Bustan region, Egypt. The study involved five treatments: control, incorporating $1 \%$ of wheat straw, $1 \%$ clover straw, $1 \%$ mixture of wheat $\&$ clover, and $1 \%$ chicken manure into sandy soil on the basis of air dry weight. Soil samples were incubated at field capacity for $7,14,28,42$ and 56 days at $30 \mathrm{C}^{0} \pm 1$. Water-stable aggregate size distribution (1.19-2, $0.5-1.19,0 \cdot 25-0.5 \mathrm{~mm}$ ) was determined through wet sieving. The organic wastes treatments improved soil aggregate stability compared with control treatment. The changes in aggregate stability indices (mean weight diameter (MWD), Structure coefficient $\left(C_{r}\right)$, detachability index (DI), percentage of aggregate destruction (PAD) and Wet aggregate stability (WAS) were determined and calculated weekly over the periods of incubation. The application of organic wastes significantly increased all aggregate stability indices compared to the control treatment except PAD. Soil aggregate indices had significant positive correlations between each other. MWD, $C_{r}$, WAS and DI values were the highest in chicken manure treatment, while the PAD values were the lowest. Disaggregation occurred in all treatments after 28 days of incubation. Polynomial function brought higher correlations between MWD, $C_{r}$, DI and PAD vs. the incubation period of sandy soil amended with organic wastes. The $C_{r}$, DI and PAD vs. MWD produced linear relationship with high correlations.
\end{abstract}

Key words: Organic wastes, Aggregate stability; wet sieving; Mean weight diameter; Structure coefficient; detachability index; percentage of aggregate destruction

\section{INTRODUCTION}

Poor soil structural stability is a serious and increasing problem in several areas of the world. An appropriate management of organic matter additions to the newly reclaimed sandy soils in Egypt may increase aggregate stability. A soil aggregate is an assemblage of closely packed sand, silt, clay, and organic particles (Cambardella, 2006). Soil aggregation is a buildup process from primary particles to micro-aggregates $(0.020$ to $0.250 \mathrm{~mm})$ and macro-aggregates $(>0.250$ $\mathrm{mm})$ and loss of soil organic carbon with cultivation is connected to the destruction of macro aggregates (Tisdall and Oades, 1982; Elliott, 1986). Soil aggregation is quantified by the distribution of sievesize fractions of soil aggregates (Angers et al., 2008;
Larney, 2008). The sieve-size fractions are synthesized by indices such as mean weight diameter (Hillel, 2004), structure coefficient (Elshafei and Ragab, 1976), percentage of aggregate destruction (Kemper and Roseneu, 1986) and detachability index.

Organic matter stabilize aggregates by increasing the inter-particle cohesion within aggregates and thus decreasing their breakdown to the breakdown mechanisms (slaking; differential swelling; raindrop impact and physico - chemical dispersion due to osmotic stress, Le Bissonnais, 1996). Different types of organic matter have different effects on the cohesion and hydrophobicity of soil, depending on their intrinsic characteristics and that of their decomposing micro flora or exudates. The microbial activity of straw decomposers increased both soil hydrophobicity and soil inter-particle cohesion. However, added organic matter may have strong direct effects on either soil cohesion or hydrophobicity, depending on the soil's own physico-chemical characteristics. By increasing their hydrophobicity and thus decreasing their breakdown by slaking. (Cosentino et al., 2006).

The effect of different organic materials on wet aggregate stability is affected by their decomposability. Organic materials rich in easily decomposable compounds, e.g. clover straw cause the formation of higher water aggregates stability but quickly decreased, while that with slowly decomposable compounds gave less WAS but last for longer period (Tisdall and Oades, 1982). The addition of clover, wheat straw and cotton stalks to Egyptian silty loam and calcareous sandy loam soils resulted in a significant increase in water aggregate stability more than $4.76 \mathrm{~mm}$. and a decrease in those of 0.21 to $1.0 \mathrm{~mm}$ diameter. The maximum increase was observed after 1-2 weeks incubation leading to a constant level until 7 weeks incubation, clover straw showed more increase in WSA than either cotton stalks or wheat straw (Gomah, 1982). He showed also that the addition of these plant residues to such soils caused a logarithmic in the structure coefficient. Wet aggregate stability of a clay loam soil due to tobacco waste application was monitored for 240 days. After incorporating 5\% tobacco waste into soil according to oven dry weight basis, soil samples were incubated at field capacity for $20,40,80,140$ and 240 days under a

${ }^{1}$ Soil and Water Sciences Department, Faculty of Agriculture, 
greenhouse condition. Tobacco waste application significantly increased all soil properties over the control treatment. Disaggregation occurred in all treatments after 20 days of incubation due to probably the more substrate demands of microorganisms in soil (Gulser, 2010). The application of manure and organic fertilizer increases the percentage of large sized water stable aggregates ( $>5 \mathrm{~mm}$ ) (Aoyama et al., 1999 and Wang et al., 2013). Usually, there was a significant positive correlation between mean weight diameter (MWD) and the amount of $>0.25 \mathrm{~mm}$ aggregates (Guber et al., 2005).Most of organic fertilizer treatments had large MWD and high amount of > $0.25 \mathrm{~mm}$ aggregates (Wang et al., 2013).

No trend is evident in the effect of the rate of organic inputs or the effect of the soil characteristics (essentially carbon and clay contents) on aggregate stability (Abiven et al., 2009). A significant negative linear correlation was found between quantities of small macro- aggregates and the $\mathrm{C} / \mathrm{N}$ ratio of the residues and a trend of positive linear correlation with $\mathrm{N}$ content of the residues was also found. However, polynomial function can bring about higher correlations than the linear function for the relations between small macroaggregates and $\mathrm{C} / \mathrm{N}$ ratios. This shows that residues with intermediate values of the quality parameters including carbon, lignin, polyphenols , lignin/ $\mathrm{N}$, polyphenols/ $\mathrm{N}$ and (lignin polyphenols)/N., i.e. the tamarind, formed high quantities of small macroaggregates, which, in turn, led to the increased MWD (Samahadthal et al., 2010 ).So, wet aggregate size distribution and related soil structure indices are essential parameters for understanding the role of soil amendments in binding of aggregates and evaluating the degree of its stability...Effects of composted tobacco waste, chicken manure and bio-humus applied during a period of three years on a coarse textured soil (Typic Xerofluvent) at Agriculture Faculty's Research and Practise Farmyard of Ege University located on Menemen plain (Izmir, Turkey) on soil physical properties were studied (M. Cercioglu et al. 2014).Composted tobacco waste and chicken manure and bio-humus from plant residuals were applied at rates of $50 \mathrm{t}$ ha-1, $4 \mathrm{t}$ ha-1, $10 \mathrm{t}$ ha-1, respectively. Inorganic fertilizers (N-P-K) are also added with chicken manure and bio-humus plots. The addition of organic wastes resulted in a significant $(\mathrm{p} \leq 0.05)$ increase in structure stability index of soil samples when compared to the control. The main objective of this study was to determine the effect of adding wheat straw, clover straw and chicken manure at specific concentration ( $1 \%$ on weight basis) on different aggregate stability indices under different incubation period in sandy soil.

\section{MATERIALS AND METHODS}

\section{Soil sampling and analyses}

The soil of the study area (Al-Bustan region, Egypt) was classified as Typic torripsamments (Labib and Khalil, 1977). Undisturbed soil samples were collected from different sites of the study area; air dried and sieved through a $2 \mathrm{~mm}$ screen. Soil $\mathrm{pH}$, ECe, and $\mathrm{CaCO}_{3}$ values were 8.3, $1.2 \mathrm{dS} . \mathrm{m}^{-1}$, and $2.4 \%$, respectively. The textural class at the $0-20 \mathrm{~cm}$ depth was sand with $95 \%$ sand, $3 \%$ silt, and $2 \%$ clay. Dry bulk density was $\left(1.67 \mathrm{Mg} \cdot \mathrm{m}^{-3}\right)$ determined by core method (Black and Hartge, 1986). Saturated hydraulic conductivity was $\left(0.78 \mathrm{~cm} \mathrm{~min}^{-1}\right)$ measured by the constant head method according to Klute and Dirksen (1986). Particle size distribution was determined by the Bouyoucos hydrometer method (Bouyoucos, 1962). Total salt, $\mathrm{pH}$ and calcium carbonate content were determined by the procedures outlined in (Page et al., 1982). Soil organic matter (OM) was determined by 'Walkely-Black' method (Nelson and Sommers, 1982).

25 Petri dishes were prepared and each one filled with one hundred grams of air dry sandy soil passed through $2 \mathrm{~mm}$ sieve to produce bulk density $=1.67$ Mg.m. ${ }^{-3}$. On air dry weight basis, $1 \%$ of each of wheat, clover straw, wheat + clover straw, and chicken manure passed through $2 \mathrm{~mm}$ sieve were incorporated into 20 Petri dishes homogenously plus 5 Petri dishes as control (without adding organic wastes). Five replicates under five different incubation periods $(7,14,28,42$ and 56 days) were done. The moisture content was adjusted at field capacity ( $9 \%$ on weight basis) using distilled water by weighing 2 days interval during the study period. Wet aggregate stability was determined by the wet sieving method reported by Kemper and Rosenau, 1986. The equivalent of $20 \mathrm{~g}$ of soil sample was placed on a set of sieves with $2,1.19,0.5$ and $0.25 \mathrm{~mm}$ in diameter. The sieves were lowered to the water surface and the soil sample was wetting by capillarity for $5 \mathrm{~min}$. The apparatus had a vertical stroke of $3 \mathrm{~cm}$, and was operated for $15 \mathrm{~min}$ at a speed of 33 cycles per minute. The fractions left on the each sieve at the end of sieving were oven dried at $105^{\circ} \mathrm{C}$ to constant mass.

\section{Data analysis}

a): The mean weight diameter (MWD) of the water stable aggregates is calculated according to Hillel, (2004):

$M W D=\sum_{i=1}^{n} x_{i} w_{i}$

Where MWD is the mean weight diameter of water stable aggregates $(\mathrm{mm}), \mathrm{w}_{\mathrm{i}}$ is the weight percentage of each aggregate size class with respect to the total sample and $\mathrm{X}_{\mathrm{i}}$ is the mean diameter of each class $(\mathrm{mm})$. 


\section{b): The structure coefficient $\left(C_{\mathbf{r}}\right)$}

Structure coefficient $\left(\mathrm{C}_{\mathbf{r}}\right)$ as suggested by El-Shafei and Ragab (1976) is calculated in order to show the aggregating capacity to compare quantitatively between treatments. This coefficient is the ratio of the percentage content of total amounts of aggregates higher than 0.25 $\mathrm{mm}$ diameter to the percentage content of that less than $0.25 \mathrm{~mm}$. The structure coefficient $(\mathrm{Cr})$, is calculated as follows:

$$
C_{r}=\frac{\% \text { aggregates }>0.25 \mathrm{~mm} \text { in diameter }}{\% \text { aggregates }<0.25 \mathrm{~m} \text { in diameter }} .
$$

c): Wet aggregate stability (WAS) in each of the following size ranges of 1.19- 2.0, 0.5- 1.19 and 0.25- $0.50 \mathrm{~mm}$ is given by Yoder, (1936) as follows:

$$
\mathrm{W} A S(\%)=\left(\frac{m}{M}\right)=100
$$

Where $\mathrm{m}$ is the mass of water stable aggregate fractions in gm, and $M$ is the total mass of the soil sample used in gm.

d): percentage of aggregate destruction (PAD) was calculated according to Kemper and Roseneu, (1986):

$\operatorname{PAD}=\left(\mathrm{M}_{\mathbf{d}}-\mathrm{M}_{\mathrm{w}}\right) * 100 / \mathrm{M}_{\mathbf{d}}$

Where $M_{d}$ is the mass fraction of $>0.25 \mathrm{~mm}$ aggregates (dry sieved) and $\mathrm{M}_{\mathrm{w}}$ is the mass fraction of $>0.25 \mathrm{~mm}$ aggregates (wet sieved)

e): Detachability index (DI), which is the ratio of the MWD $_{w}$ after wet sieving to that before wet sieving $\left(\mathrm{MWD}_{\mathrm{d}}\right)$

(The dry sieve analysis has been done to calculate both PAD and DI).

\section{Statistical Analysis}

All statistical analyses were performed with Costat (version 6.303) and Microsoft Office Excel 2007 programs. Tow-way analysis of variance was performed to determine the effects of addition $1 \%$ of each wheat, clover, mixed of wheat + clover straw and chicken manure and incubation period on aggregate stability indices of coarse textured soil (Typic torripsamments ).

\section{RESULTS AND DISCUSSIONS}

This part of article includes the results and discussion the effect of some occupied organic materials on stability of aggregates and its ability to resist the deformation forces. The effect of agricultural wastes manure and Incubation Period on wet aggregate stability and other aggregate stability indices in sandy soil was studied. Two simple parameters regression models $\left[2^{\text {nd }}\right.$ order polynomial and linear $]$ were used to study the possible correlations between mean weight diameter (MWD), structure coefficient $\left(\mathrm{C}_{\mathrm{r}}\right)$ vs. incubation periods as well as the relationship between structure coefficient $\left(\mathrm{C}_{\mathrm{r}}\right)$, Detachability Index (DI) and Percentage of aggregate destruction (PAD) vs. mean weight diameter (MWD).

\section{Wet- Aggregate Stability (WAS)}

Organic amendments usually used to improve physical characteristics of sandy soils. One of the important physical properties is aggregate stability. The effect of adding $1 \%$ of wheat and clover straw, and chicken manure to the sandy soil on wet sieving stability (WAS) presented in Figure 1. The highest values of WAS were found in soil fraction of $0.25-0.5$ $\mathrm{mm}$ after 28 days incubation (Fig.1) followed by $0.5-$ $1.19 \mathrm{~mm}$. In general, the lowest WAS values were found in soil fraction $1.19-2.0 \mathrm{~mm}$ (data not shown).

The maximum value of WAS (20.6 \%) was in chicken manure treatment after 28 days of incubation followed by clover straw treatment (19.3). The wheat straw treatment showed the lowest WAS values $(16.7 \%)$ as shown in Figure 2. Therefore, the percentage of macro- aggregates $(>0.250 \mathrm{~mm})$, after 28 days, increased compared to control as follows $8.7 \%$, $13.8 \%, 15.4 \%, 18.2 \%$ in wheat straw, wheat + clover straw, clover straw and chicken manure treatments, respectively. The increase of WAS due to addition of these organic wastes could be explained on the basis that such organic materials could either increase the number and activity of total bacteria and molds that stimulate the biological decomposition of such organic materials resulting in many organic binding agent or that the hyphae of soil fungi and actinomycetes could bound the single particles together. Also, such addition could enhance the formation of microbial gums, which could act as soil binding agent.

Gomah (1982) showed that the addition of organic wastes to silty clay loam and calcareous soils increased the number of total bacteria and molds as well as microbial gums. Also, Metzger et al., (1987) found that the amendment of loose sandy clay loam soil with sludge increased WSA $>200$ micron and the number of bacteria and fungi. Similar effects were found by (Lynch and Bragg, 1985) and Tisdall Oades, 1982). The greater observed effect of both chicken and compost on WAS could be due to that such amendment contain humic substances that play a major role in the formation of WAS, in addition to the higher increase of the number of total bacteria and molds result in such treatment.

There are a significant relation between the wet aggregate stability under different organic mulches treatments and incubation periods as well as the interaction between wastes treatments and incubation periods (Table. 1). 


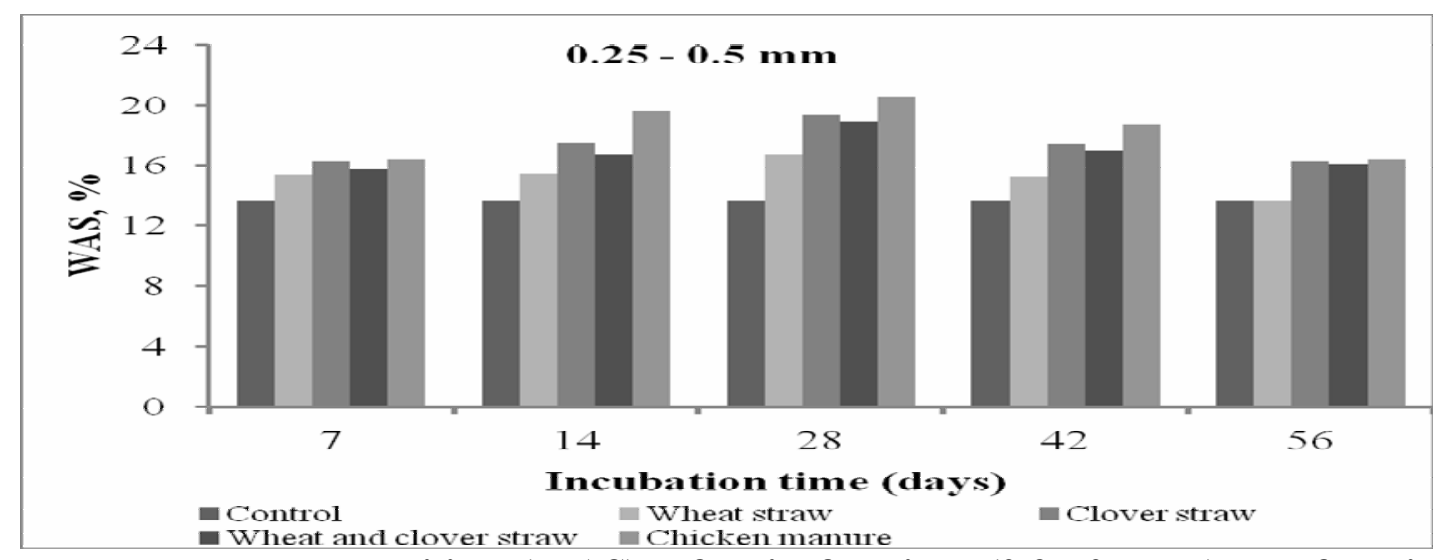

Fig. 1. Wet- aggregate stability (WAS) of soil fraction $(0.25-0.5 \mathrm{~mm})$ as function of incubation time

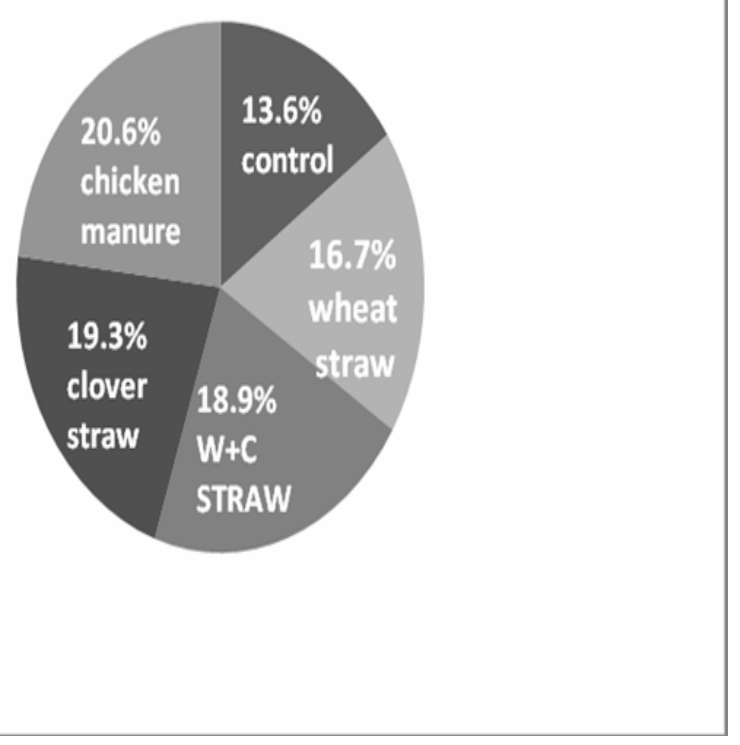

Fig. 2. Wet aggregate stability(WAS) of soil fraction $0.25-0.5 \mathrm{~mm}$ after 28 days of incubation under different organic wastes treatments

Table 1. Effect of organic wastes on the wet aggregate stability(WAS, \%) under different incubation periods

\begin{tabular}{lcccccc}
\hline Treatments(T) & \multicolumn{3}{c}{ Incubation period, days (I) } & \multicolumn{2}{c}{ LSD0.05 $=\mathbf{0 . 3 4}$} \\
\cline { 2 - 6 } & $\mathbf{7}$ & $\mathbf{1 4}$ & $\mathbf{2 8}$ & $\mathbf{4 2}$ & $\mathbf{5 6}$ & Mean \\
\hline chicken manure & 16.4 & 19.6 & 20.6 & 18.7 & 16.4 & $18.34 \mathrm{a}$ \\
\hline clover straw & 16.3 & 17.5 & 19.3 & 17.4 & 16.3 & $17.36 \mathrm{~b}$ \\
\hline wheat+ clover straw & 15.7 & 16.7 & 18.9 & 17 & 16.1 & $16.88 \mathrm{c}$ \\
\hline wheat straw & 15.3 & 15.4 & 16.7 & 15.2 & 13.6 & $15.24 \mathrm{~d}$ \\
\hline control & 13.6 & 13.6 & 13.6 & 13.6 & 13.6 & $13.60 \mathrm{e}$ \\
\hline Mean & $15.46 \mathrm{c}$ & $16.56 \mathrm{~b}$ & $17.82 \mathrm{a}$ & $16.38 \mathrm{~b}$ & $15.28 \mathrm{c}$ & LSD $0.05=0.34$ \\
\hline
\end{tabular}

Treatments $(\mathrm{T}) * * *$

Incubation period $(\mathrm{I})^{* * *}$

$\mathrm{T}$ and $\mathrm{I}$ interaction*** 
2. Mean weigh diameter (MWD) and Structure coefficient $(\mathrm{Cr})$

The effect of applied organic wastes on MWD and $\mathrm{C}_{\mathbf{r}}$ values is presented in Tables (2 and 3) and Figures (3 and 4). There was marked increase in MWD and $\mathrm{Cr}$ as a result of addition different organic wastes after 7 days up to 28 days of incubation then decreased thereafter depending on the type of the organic materials. Chicken manure showed the highest increase in MWD and $\mathrm{C}_{\mathrm{r}}$ followed by clover, wheat + clover and wheat straw treatments. The increased values of MWD and $\mathrm{C}_{\mathbf{r}}$ might due to the mechanical binding of soil particles together and by the production of effective binding agents either by synthesis or through the decomposition of organic materials (Oades, 1984) and these results are in harmony with that obtained by Gomah (1982). Polynomial function can bring about higher correlations between MWD and $\mathrm{C}_{\mathbf{r}}$ vs. incubation time of soil amended with organic mulches as shown in Table (1). This results are in agreement with finding of Abiven et al., (2009) and Samahadthal et al., (2010).

It concludes, the maximum values of mean weight diameter (MWD), structure coefficient $\left(\mathrm{C}_{\mathrm{r}}\right)$ and wetaggregate stability (WAS) were produced after 28 days of organic materials applications. MWD, $\mathbf{C}_{\mathrm{r}}$, and
WAS values between 28 and 42 days decreased probably due to increasing substrate demands of bacteria in soils and bacterial attack on products which bind soil particles together reduces stability. Improved aggregate stability by addition of organic residue to soils is a result of released plant phenolic acid interactions during the decomposition of residues structural components and increasing microbial activity due to carbohydrates metabolisms (Martens, 2000). Polynomial function brought higher correlations between MWD and $C_{r}$ vs. the incubation period of sandy soil mixed with different agriculture organic wastes (Table. 4).

3. Detachability Index (DI) and Percentage of aggregate destruction (PAD)

The values of DI and PAD are illustrated in Figures 5 and 6 . The results indicated that an increase in DI values as a result of applied different organic materials after 7 days incubation then decreased thereafter depending on the type of the organic amendment. Chicken manure showed the highest increase in DI under all treatments (Fig 5).

Table 2. Effect of organic wastes on mean weight diameter (MWD) under different incubation periods

\begin{tabular}{lcccccc}
\hline & \multicolumn{5}{c}{$\begin{array}{c}\text { MWD, mm } \\
\text { Incubation periods, days }\end{array}$} \\
\hline Treatments & $\mathbf{7}$ & $\mathbf{1 4}$ & $\mathbf{2 8}$ & $\mathbf{4 2}$ & $\mathbf{5 6}$ & Mean \\
\hline Control & 0.23 & 0.23 & 0.23 & 0.23 & 0.23 & $0.230 \mathrm{e}$ \\
\hline Wheat Straw & 0.258 & 0.284 & 0.303 & 0.276 & 0.252 & $0.275 \mathrm{~d}$ \\
\hline Clover Straw & 0.272 & 0.328 & 0.357 & 0.325 & 0.298 & $0.316 \mathrm{~b}$ \\
\hline Wheat + Clover St. & 0.265 & 0.294 & 0.341 & 0.314 & 0.292 & $0.301 \mathrm{c}$ \\
\hline Chicken manure & 0.293 & 0.347 & 0.379 & 0.345 & 0.305 & $0.338 \mathrm{a}$ \\
\hline Mean & $0.263 \mathrm{~d}$ & $0.297 \mathrm{~b}$ & $0.322 \mathrm{a}$ & $0.298 \mathrm{~b}$ & $0.275 \mathbf{c}$ & LSD $_{\mathbf{0 . 0 5}}=0.007$ \\
\hline
\end{tabular}

Table 3. Effect of organic materials on structure coefficient $\left(c_{r}\right)$ under different incubation periods

\section{Structure coefficient $\left(\mathrm{c}_{\mathrm{r}}\right)$}

Incubation periods, days

\begin{tabular}{lcccccc} 
& \multicolumn{1}{c}{ Mean } \\
\hline Treatments & $\mathbf{7}$ & $\mathbf{1 4}$ & $\mathbf{2 8}$ & $\mathbf{4 2}$ & $\mathbf{5 6}$ & LSD $_{\mathbf{0 . 0 5}}=\mathbf{0 . 0 2 8}$ \\
\hline Control & 0.4 & 0.4 & 0.4 & 0.4 & 0.4 & $0.400 \mathrm{~d}$ \\
\hline Wheat Straw & 0.47 & 0.51 & 0.59 & 0.509 & 0.47 & $0.510 \mathrm{c}$ \\
\hline Clover Straw & 0.51 & 0.625 & 0.765 & 0.685 & 0.591 & $0.629 \mathrm{~b}$ \\
\hline Wheat\& Clover St. & 0.508 & 0.596 & 0.725 & 0.624 & 0.574 & $0.605 \mathrm{~b}$ \\
\hline Chicken manure & 0.58 & 0.76 & 0.86 & 0.75 & 0.63 & $0.716 \mathrm{a}$ \\
\hline Mean & $0.493 \mathrm{~d}$ & $0.578 \mathrm{~b}$ & $0.662 \mathrm{a}$ & $0.593 \mathrm{~b}$ & $0.532 \mathrm{c}$ & LSD $_{\mathbf{0 . 0 5}}=0.028$ \\
\hline
\end{tabular}




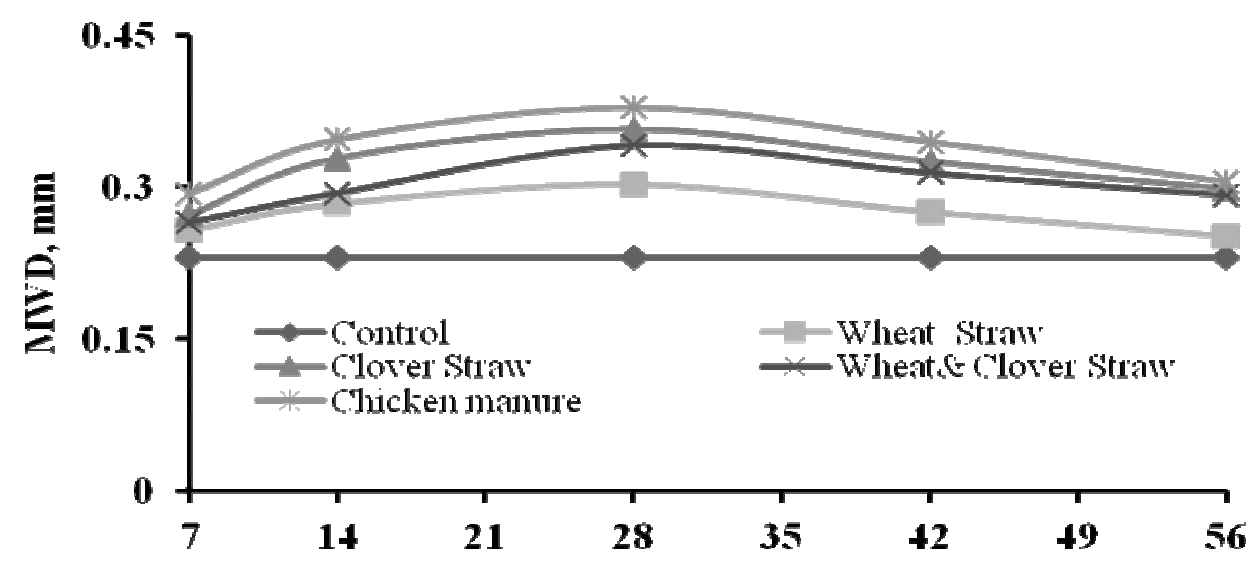

Incubation period, days

Fig. 3. Effect of different organic materials on mean weight diameter (MWD, mm) of sandy soil

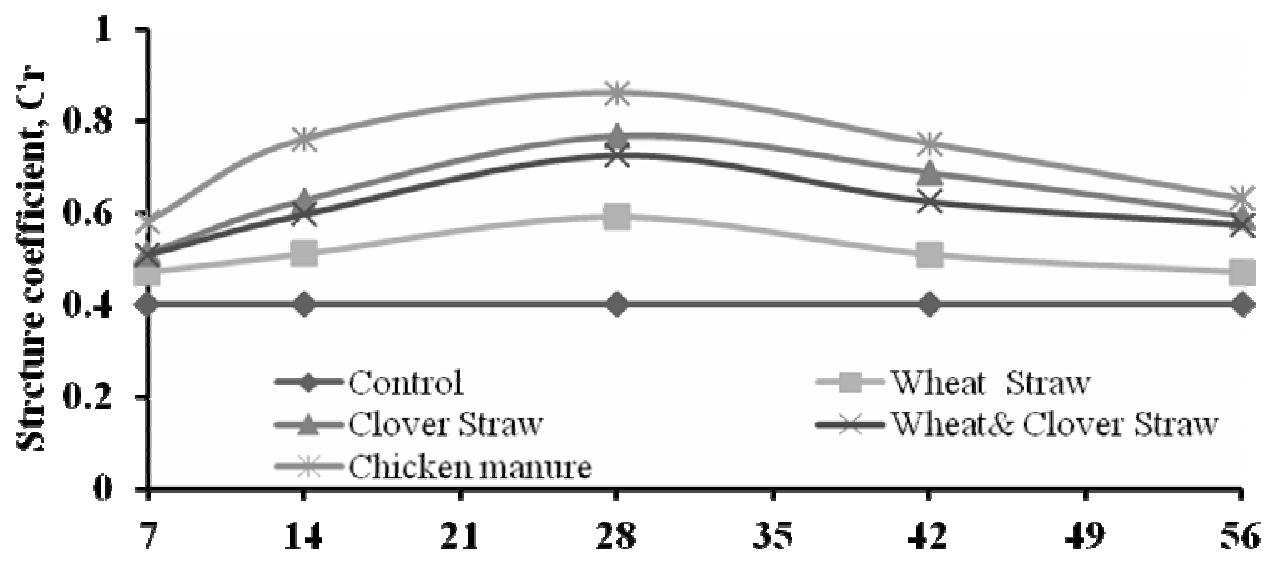

Incubation period days

Fig. 4. Effect of different organic materials on structure coefficient $\left(C_{r}\right)$ of sandy soil

Table 4. Relations between mean weight diameter, structure coefficient and incubation period under different organic wastes

\begin{tabular}{lll}
\multicolumn{1}{c}{ Organic treatments } & \multicolumn{1}{c}{ Equations } & \multicolumn{1}{c}{$\mathbf{R}^{2}$} \\
WHEAT STRAW & $\mathrm{MWD}=-7 \mathrm{E}-05 \mathrm{~T} 2+0.004 \mathrm{~T}+0273$ & 0.891 \\
& $\mathrm{Cr}=-0.000 \mathrm{~T} 2+0.009 \mathrm{~T}+0.411$ & 0.780 \\
GLOVER STRAW & $\mathrm{MWD}=0.000 \mathrm{~T} 2+0.007 \mathrm{~T}+0.238$ & 0.845 \\
\hline \hline & $\mathrm{Cr}=-0.000 \mathrm{~T} 2+0.217 \mathrm{~T}+0.381$ & 0.938 \\
\hline WHEAT+GLOVER STRAW & $\mathrm{MWD}=-9 \mathrm{E} 05 \mathrm{~T} 2+0.006 \mathrm{~T}+0.227$ & 0.900 \\
CHICKEN MANURE & $\mathrm{Cr}=-0.000 \mathrm{~T} 2+0.017 \mathrm{~T}+0.409$ & 0.833 \\
\hline \hline
\end{tabular}

Mean Weight Diameter (MWD), Structure Coefficient (Cr) and Incubation period (T) 
The maximum value of DI in chicken manure treatment was 0.5 after 28 days of incubation. The minimum value of DI was 0.31 in control treatments. Similar trend was shown in other treatments. The relation between PAD vs. incubation time as shown in Figure 6 revealed approximately the mirror of the curves depicted in figure 5 (DI vs. Incubation period). The percentage of aggregate destruction (PAD) and detachability index (DI) was influenced by microorganisms in two major ways: by the mechanical binding of soil particles together, and by the production of effective binding agents either by synthesis or through the decomposition of organic materials (Oades, 1984; Zaller, 2007). Also, polynomial function brought higher correlations between DI and PAD vs. incubation period of sandy soil amended with organic wastes (Table 5).

\section{Relations between Cr, DI and PAD and MWD}

Linear function brought about higher correlations between $\mathrm{C}_{\mathrm{r}}$, DI and PAD vs.MWD of soil amended with organic mulches as shown in Figures 7, 8, 9 and Table 6.

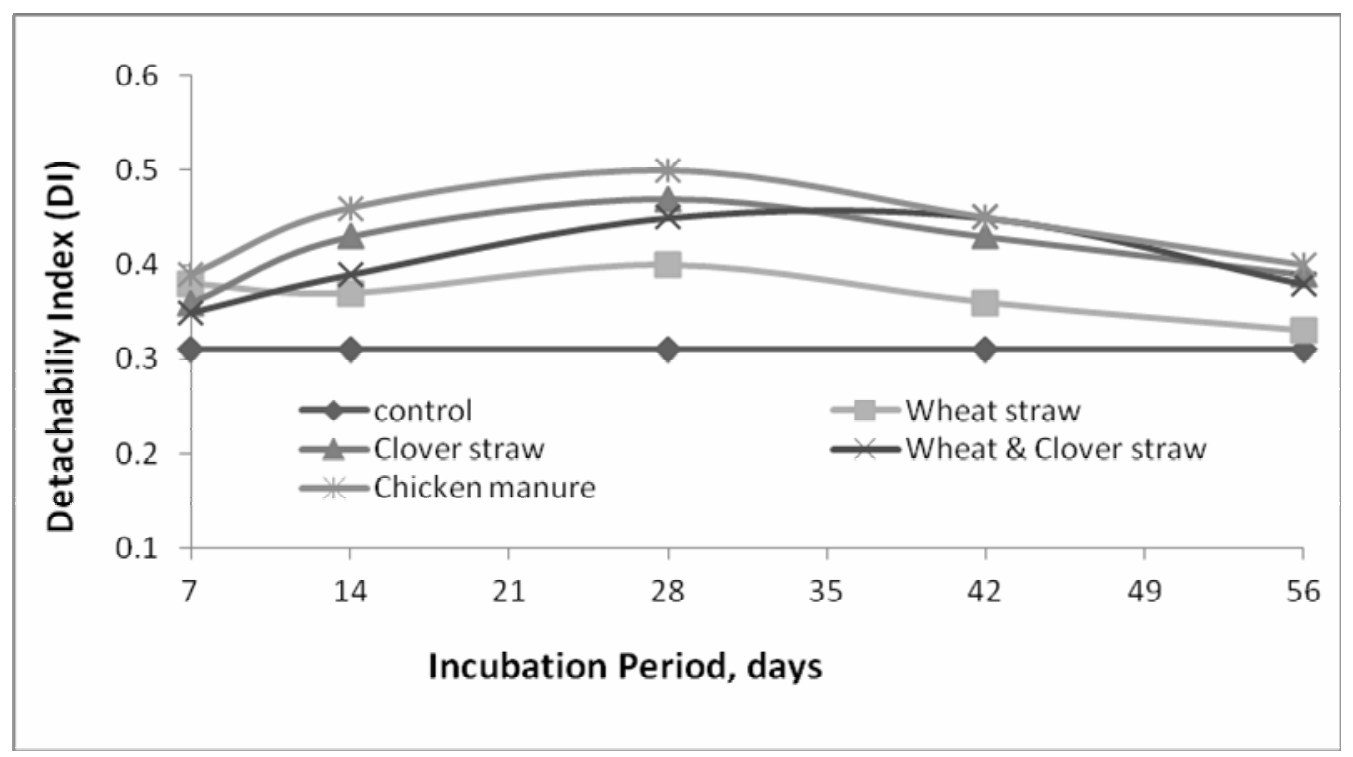

Fig. 5. Detachability Index (DI) vs. Incubation period

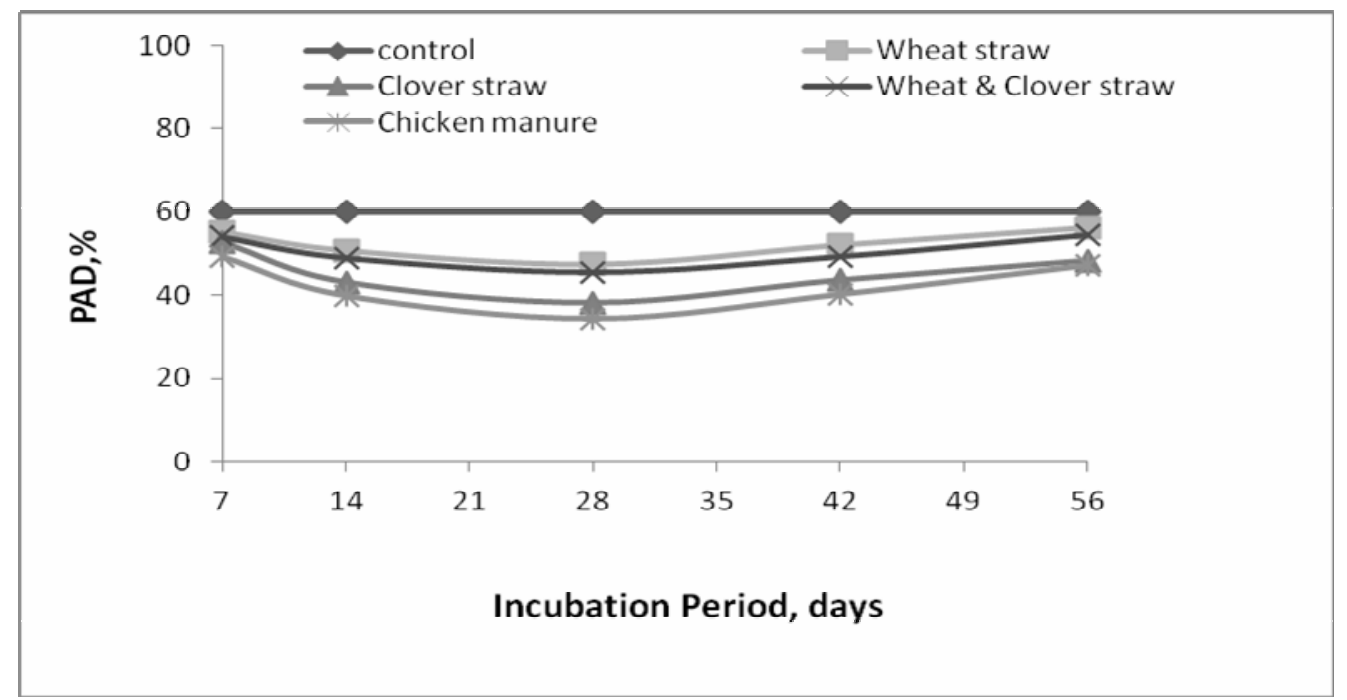

Fig. 6. Percentage of aggregate destruction (PAD) vs. Incubation period 
Table 5. Relations between detachability index, percentage of aggregate destruction and incubation period under different organic wastes

\begin{tabular}{llc}
\hline Organic treatments & \multicolumn{1}{c}{ Equations } & $\mathbf{R}^{2}$ \\
\hline & $\mathrm{DI}=-5 \mathrm{E}-05 \mathrm{~T}^{2}+0.002 \mathrm{~T}+0.358$ & 0.824 \\
WHEAT STRAW & $\mathrm{PAD}=0.011 \mathrm{~T}^{2}-0.703 \mathrm{~T}+58.93$ & 0.892 \\
\hline & $\mathrm{DI}=0.000 \mathrm{~T}^{2}+0.009 \mathrm{~T}+0.342$ & 0.883 \\
GLOVER STRAW & $\mathrm{PAD}=0.018 \mathrm{~T}^{2}-1.210 \mathrm{~T}+58.6$ & 0.845 \\
\hline & $\mathrm{DI}=0.000 \mathrm{~T}^{2}+0.01 \mathrm{~T}+0.281$ & 0.990 \\
WHEAT+GLOVER STRAW & $\mathrm{PAD}=0.013 \mathrm{~T}^{2}-0.804 \mathrm{~T}+58.4$ & 0.942 \\
\hline & $\mathrm{DI}=0.000 \mathrm{~T}^{2}+0.009 \mathrm{~T}+0342$ & 0.883 \\
CHICKEN MANURE & $\mathrm{PAD}=0.012 \mathrm{~T}^{2}-1.319 \mathrm{~T}+55.94$ & 0.904 \\
\hline
\end{tabular}

Detachability index $=(\mathrm{DI})$, Percentage of Aggregate Destruction (PAD) and Incubation period (T)

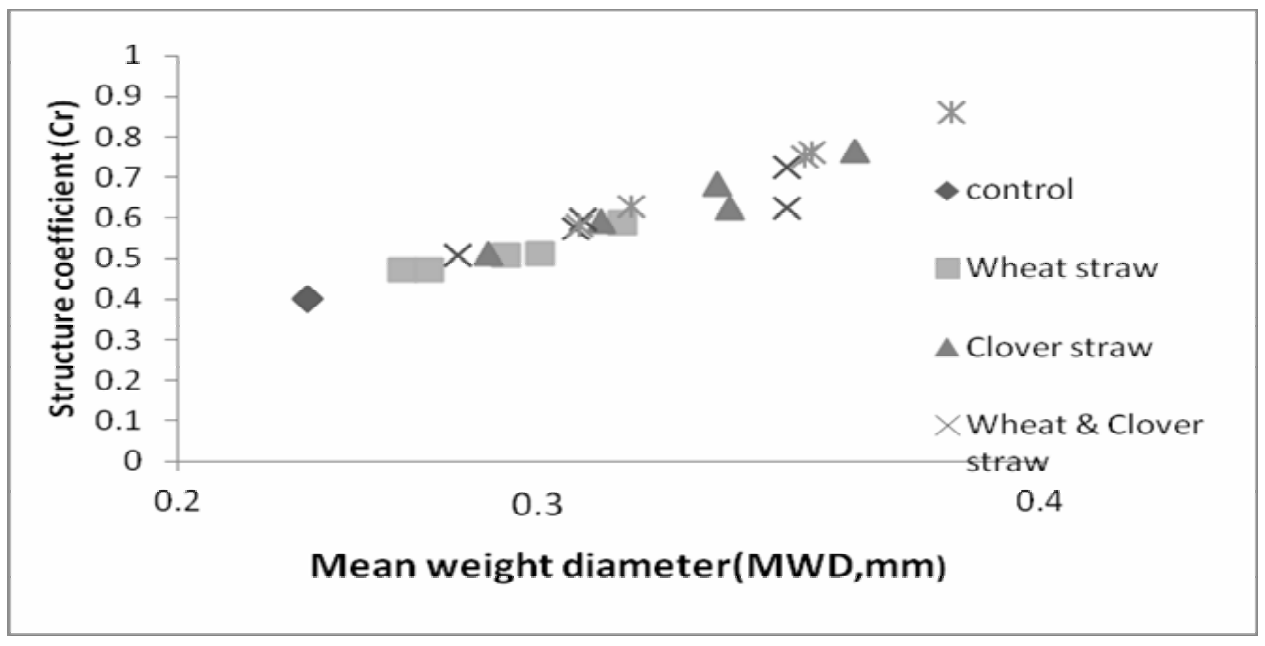

Fig. 7. Structure coefficient $\left(C_{r}\right)$ Vs. mean weight diameter (MWD) under different treatments

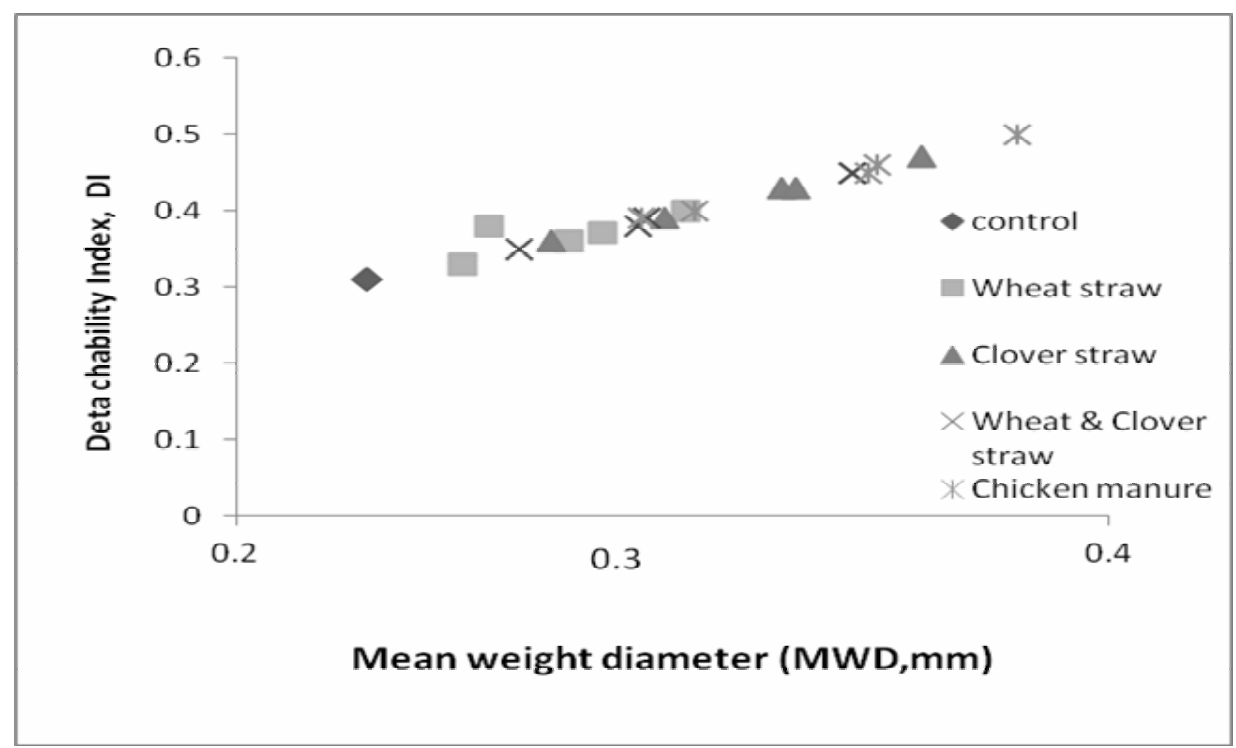

Fig. 8. Detachability index (DI) vs. mean weight diameter (MWD) under different treatments 


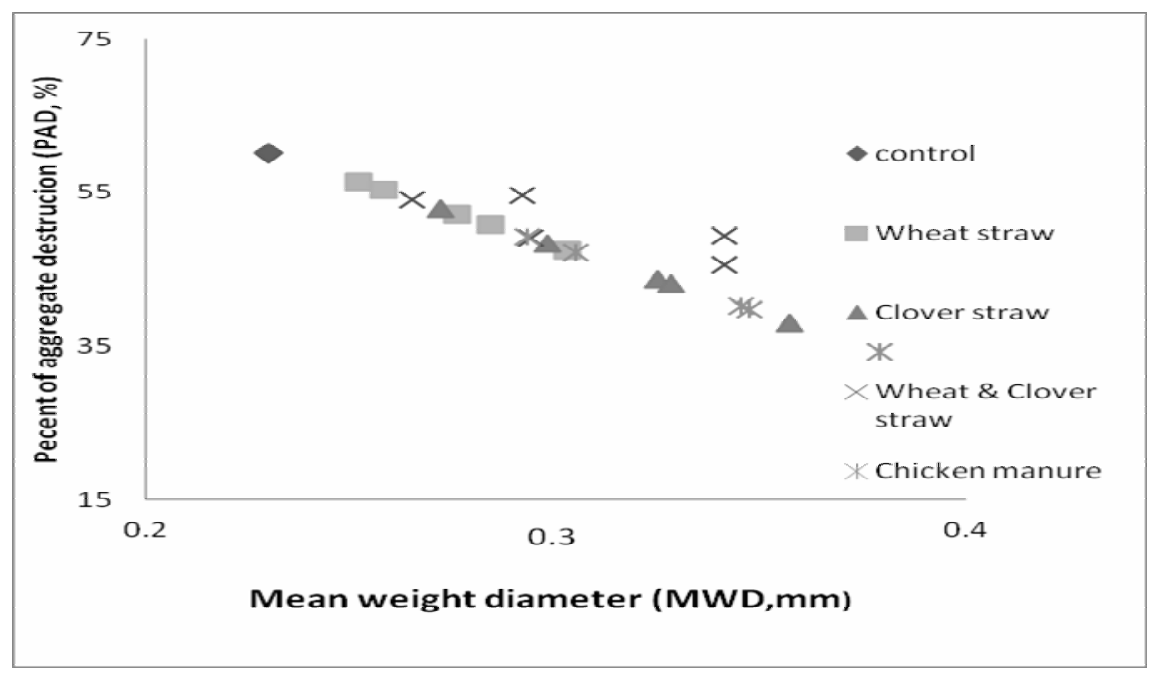

Fig. 9. Percentage of aggregate destruction (PAD) vs. mean weight diameter (MWD) under different treatments

Table 6. Relations of the Cr, DI, and PAD vs. MWD under different organic materials

\begin{tabular}{llc}
\hline Treatments & \multicolumn{1}{c}{ Equations } & $\mathbf{R}^{2}$ \\
\hline \multirow{3}{*}{ WHEAT STRAW } & $\mathrm{Cr}=2.282 \mathrm{MWD}-0.116$ & 0.911 \\
& $\mathrm{DI}=0.963 \mathrm{MWD}+0.110$ & 0.550 \\
& $\mathrm{PAD}=-173.1 \mathrm{MWD}+99.96$ & 1.0 \\
\hline \multirow{3}{*}{ GLOVER STRAW } & $\mathrm{Cr}=2.888 \mathrm{MWD}-0.271$ & 0.925 \\
& $\mathrm{DI}=1.305 .5 \mathrm{MWD}+0.003$ & 0.997 \\
& $\mathrm{PAD}=-173.5 \mathrm{MWD}+100$ & 1.0 \\
\hline \multirow{3}{*}{ WHEAT+GLOVER } & $\mathrm{Cr}=2.099 \mathrm{MWD}-.038$ & 0.781 \\
STRAW & $\mathrm{DI}=1.328 \mathrm{MWD}+0.003$ & 0.996 \\
& $\mathrm{PAD}=-88.78 \mathrm{MWD}+74.76$ & 0.619 \\
\hline \multirow{2}{*}{ CHICKEN MANURE } & $\mathrm{Cr}=3.203 \mathrm{MWD}-0.353$ & 0.998 \\
& $\mathrm{DI}=1.298 \mathrm{MWD}+0.006$ & 0.994 \\
\hline
\end{tabular}

Structure Coefficient $(\mathrm{Cr})$, Detachability index $=(\mathrm{DI})$, Percentage of Aggregate Destruction (PAD) and Mean Weight Diameter (MWD)

\section{CONCLUSIONS}

The obtained data under all the involved treatments indicated that the percentage of wet aggregate stability (WAS) was gradually increased after an incubation period of 4 weeks then showed a slight decrease until 8 weeks. The maximum value of WAS (20.6\%) was in chicken manure treatment after 28 days of incubation followed by clover straw treatment $(19.3 \%)$ while its value was $16.7 \%$ under wheat straw treatment. Control treatment showed the lowest WAS value $(13.6 \%)$.Similar trend of WAS of the other diameters and treatments were observed. However, chicken manure showed the highest effect on aggregate formation in comparison with the different organic wastes. The mean weight diameter MWD, and structure coefficient $\left(\mathrm{C}_{\mathrm{r}}\right)$ of different treatments showed the same trend. Polynomial function obtained higher correlations between MWD, $\mathrm{C}_{\mathbf{r}}$, DI and PAD vs. the incubation period of sandy soil amended with organic mulches. The $\mathrm{C}_{\mathrm{r}}$, DI and PAD vs. MWD produced linear relationship with high correlations.

\section{REFERENCES}

Abiven, S., S.Menasseri, and C.Claire Chenu, 2009. The effects of organic inputs over time on soil aggregate stability - A literature analysis. Soil Biology and Biochemistry 41: 1-12.

Angers, D. A., M. S. Bullock, and G. R. Mehuys. 2008. Aggregate stability to water. p. 811- 819 in Carter, M.R., Gregorich, E.G. (editors). Soil sampling and methods of analysis. 2nd Ed., Canadian Society of Soil Science, CRC Press, Boca Raton, FL.

Aoyama M., D.A.Angers., A. N'Dayegamiye.and N. Bissonnette 1999. Protected organic matter in water-stable aggregates as affected by mineral fertilizer and manure applications. Canadian Journal of Soil Sci. 79: 419-425. 
Black, G.R., and K.H. Hartge. 1986. Bulk density. In: Klute, A. (ed.), Methods of Soil Analysis. Part 1. Physical and Mineralogical Methods, second ed. Agronomy Monograph, 9. ASA-SSA, Madison, WI, pp. 363-375.

Bouyoucos, G.J., 1962. Hydrometer method improved for making particle size analyses of soil. Agron. J. 54:464465.

Cambardella, C. A. 2006. Aggregation and organic matter. p. 52-55 in Lal, R. (Editor). Encyclopedia of Soil Science. Taylor and Francis, Boca Raton, FL.

Cercioglu M., O.Bülent, D.Sezai, and A.R. Ongun.2014. Changes in physical conditions of a coarse textured soil by addition of organic wastes. Eurasian J. of Soil Sci. 3: 7 12.

Cosentino, D., Y.Le Bissonnais, and C. Chenu. 2006. Aggregate stability and microbial community dynamics under drying-wetting cycles in a silt loam soil. Soil Biology and Biochemistry. 38: 2053-2062.

Elliot, E.T. 1986. Aggregate structure and carbon nitrogen, and phosphorus in native and cultivated soils. Soil Sci. Soc. Am. J.50: 627-633.

El-Shafei, Y.Z., and R.A. Ragab. 1976. Soil Surface sealing Caused by rain drop impact. Egypt. J. Soil Sci., 16: 47-68

Gomah, A.M. 1982. Organic Materials and soil productivity in the near east. FAO soil Bulletin 45. Rome.

Guber A.K., Ya.A.Pachepsky, and E.V. Levkovsky. 2005. Fractal mass-size scaling of wetting soil aggregates. Ecological Modelling. 182: 317-322.

Gulser, C., Z.Dimer, and Ic Serkan. 2010. Changes in some soil properties after different incubation periods. J. Environmental biology.31: 671- 674 .

Hillel, D. 2004. Introduction to Environmental Soil Physics. Elsevier, Amsterdam, 494 p.

Kemper, W.D. and R.C. Rosenau. 1986. Aggregate stability and size distribution In: Methods of Soil Analysis, 2nd Edn. Part I. (Ed.: A. Klute) ASA, Madison, WI. pp. 425442.

Klute, A.and C.Direksen. 1986. Hydraulic conductivity and diffusivity. In: Klute, A(Ed.), Methods of soil Analysis. Part 1. Physical and Mineralogical Method, second ed. Agronomy Monographs, 9. ASA-SSA, Madison,WI, pp. 687-734.

Labib,F., and J.B.Khlil.1977. Pedological study of some sediments in the Western Desert. Egypt J. Soil Sci. 17: 203- 221.
Larney, F. J. 2008 Dry-aggregate size distribution. p. 821-83 in Carter, M.R., Gregorich, E.G. (editors). Soil sampling and methods of analysis. 2nd Ed., Canadian Society of Soil Science, CRC Press, Boca Raton, FL.

Lynch, J.M., and E. Bragg. 1985. Microorganisms and soil aggregate stability: In advances in Soil Science, vol.2. Stewart, B.A.(Eds). Springer- Verlag New York, Inc. pp 132-171,

Le Bissonnais, Y., 1996. Soil characteristics and aggregate stability. In: Agassi, M. (Ed.), Soil Erosion, Conservation and Rehabilitation. Dekker,NewYork, pp. 41-60.

Martens, D.A. 2000. Plant residue biochemistry regulates soil carbon cycling and carbon sequestration. Soil Biol. Biochem. 32: 361-369.

Metzger, L., D. Levanon and U. Mingelgrin. 1987. The effect of Sewage sludge on soil structural stability: Microbiological aspects. Soil Sci. Soc Am. J. 51: 346-351.

Nelson, D.W., and L.E.Sommers.1982. Total carbon, organic carbon, and organic matter. In: Page, A.L. (Ed.), Methods of soil Analysis. Part 2. Chemical and Microbiological Properties, second ed. Agronomy Monographs, 9. ASASSA, Madison, WI, pp. 539-579.

Oades, J.M. 1984. Soil organic matter and structural stability: mechanisms and implication for management. Plant and Soil. 76: 319-337.

Page, A.L., R.H.Miller, and D.R.Keeney.1982. Methods of soil Analysis. Part 2. Chemical and Microbiological Properties, second ed. Agronomy Monographs, 9. ASASSA, Madison, WI.

Samahadthal, P., P. Vityakon and P. Saenjan. 2010. Effects of different quality plant residues of soil carbon accumulation and aggregate formation in a tropical sandy soil Northeast Thailand as revealed bya 10 year field experiment. Land Degrad. Develop. 21: 463-473.

Tisdall J.M. and J.M. Oades. 1982. Organic matter and waterstable aggregates in Soils J. Soil Sci. 33:141-163.

Wang, F., Y.A.Tong., J.S.Zhang., P.C.Gao., and J.N. Coffie. 2013. Effects of various organic materials on soil aggregate stability and soil microbiological properties on the Loess Plateau of China. Plant Soil Environ. 59,(4): 162-168.

Yoder, R. E. 1936. A direct method of aggregate analysis of soils and a study of the physical nature of erosion losses. J. Am. Soc. Argon. 28:337-351. 


\section{المالخص الهري \\ تأثير المخلف الزراعية وفترة تحضينها عل شبلت الحبيبل المركبة ف التربة الرملية \\ لحمد فريسعد}

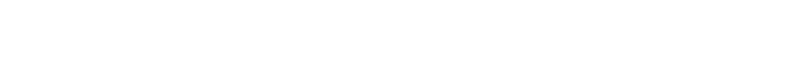

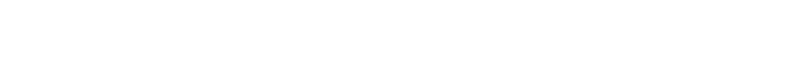

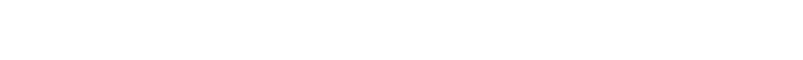

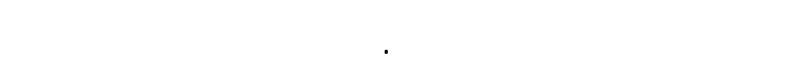

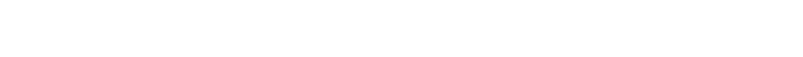

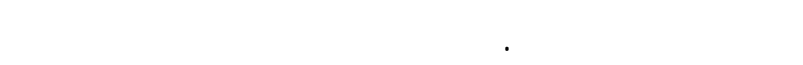

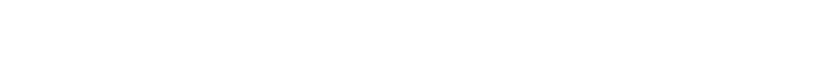

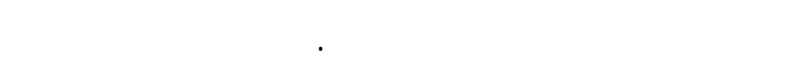

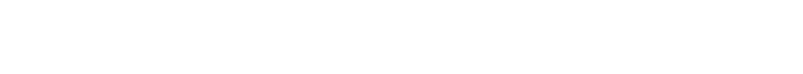

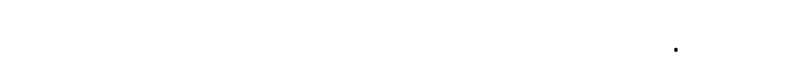

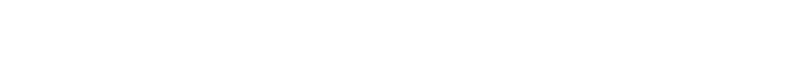

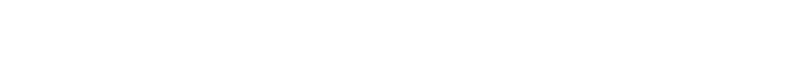

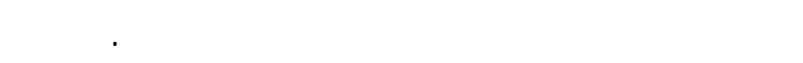

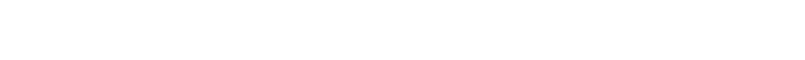

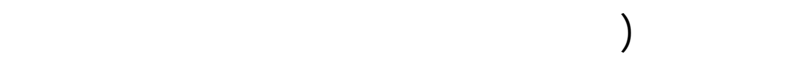

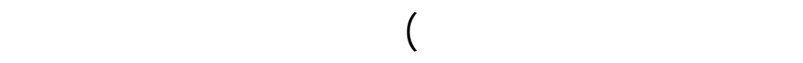

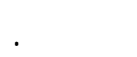

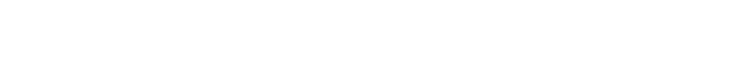

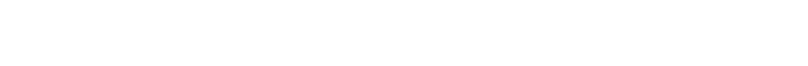

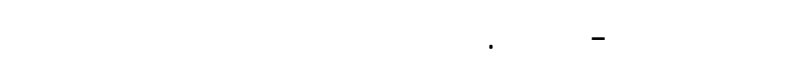

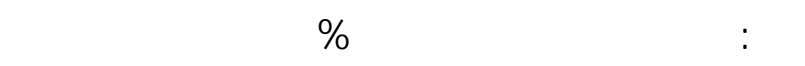

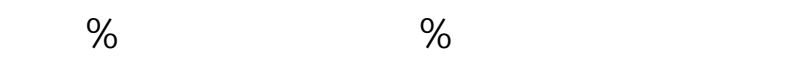

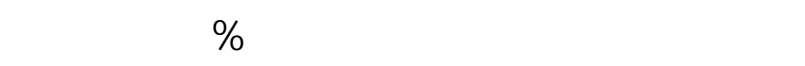

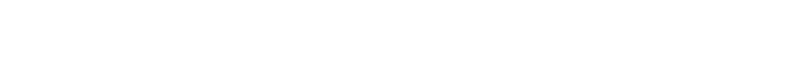

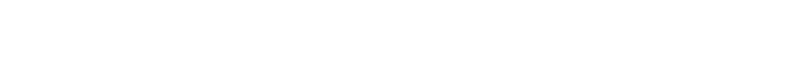

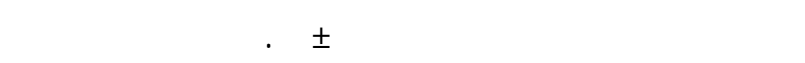

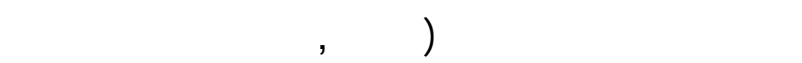

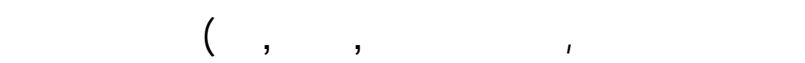

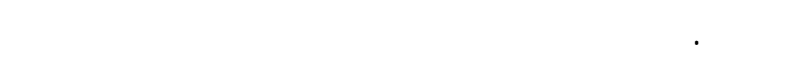
الحبيبت في التربة الرملية بالمقارنة بمعلملة الكنترول. وقد

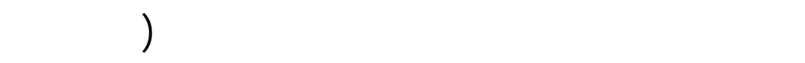

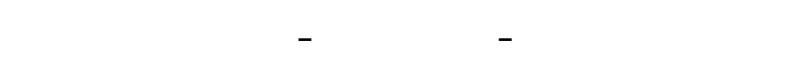

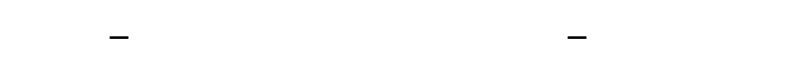

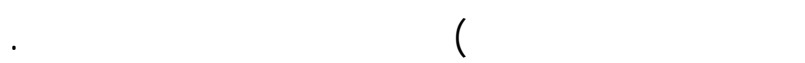

